\title{
Pengaruh Takaran Kompos Biochar Pupuk Kandang Sapi Terhadap Pertumbuhan Beberapa Kultivar Kacang Hijau (Vigna radiata L.)
}

\author{
Maria Afnita Lelang ${ }^{\mathrm{a}}$, dan Vasco Gusmao ${ }^{\mathrm{b}}$ \\ ${ }^{a}$ Fakultas Pertanian, Universitas Timor, Kefamenanu, TTU - NTT, Indonesia, email: afnitalelang@gmail.com \\ ${ }^{b}$ Fakultas Pertanian, Universitas Timor, Kefamenanu, TTU - NTT, Indonesia, email: vascogusmao1993@gmail.com
}

\section{Article Info}

Article history:

Received 21 Mei 2019

Received in revised form 20 Agustus 2019 Accepted 25 Oktober 2019

https://doi.org/10.32938/sc.v4i02.691

Keywords:

Kompos biochar

Kultivar kacang hijau

Pertumbuhan tanaman

\section{Abstrak}

Penelitian ini bertujuan untuk mengetahui respon kultivar kacang hijau terhadap aplikasi kompos biochar dan pengaruh takaran kompos biochar terhadap pertumbuhan dan hasil tanaman kacang hijau serta takaran kompos biochar terbaik terhadap pertumbuhan dan hasi tanaman kacang hijau, kacang kuning dan kacang hitam. Penelitian ini menggunakan Rancangan Acak Kelompok faktorial $4 \times 3$ yang diulang 3 kali. Faktor pertama adalah takaran kompos biochar pupuk kandang Sapi yang terdiri dari 4 aras yakni kontrol 0 t/ha, 10 t/ha, 15 t/ha, 20 t/ha. Faktor kedua yaitu jenis kacang hijau lokal Timor terdiri, Fore Belu, Kacang hitam dan Kacang kuning yang diulang 3 kali sehingga terdapat 36 unit perlakuan. Parameter yang diamati dalam penelitian ini adalah parameter lingkungan, parameter pertumbuhan dan parameter hasil. Hasil penelitian menunjukkan tidak terjadi interaksi antara perlakuan takaran kompos biochar dengan jenis kacang terhadap semua parameter pengamatan kecuali pada parameter pengamatan tinggi tanaman 21 hst, panjang akar 35 hst, total bintil akar 50 hst, dan jumlah polong per tanaman. Kompos biochar berpengaruh terhadap pertumbuhan dan hasil tanaman kacang hijau. Jenis kacang hijau berpengaruh terhadap pertumbuhan dan hasil tanaman. Takaran terbaik untuk jenis kacang hijau Fore Belu adalah 20 $\mathrm{t} / \mathrm{ha}$, kuning $15 \mathrm{t} / \mathrm{ha}$, hitam $15 \mathrm{t} / \mathrm{ha}$.

\section{Pendahuluan}

Tanaman kacang hijau dapat meningkatkan gizi pangan keluarga karena kacang hijau banyak mengandung zat gizi yang dibutuhkan oleh tubuh manusia. Kandungan zat-zat gizi pada tanaman kacang hijau antara lain: amylum, protein, besi, belerang, kalsium, lemak, mangan magnesium, niasin, vitamin (B1, A dan E). Manfaat lain dari tanaman kacang hijau adalah dapa melancarkan buang air besar dan menambah semangat hidup, juga digunakan untuk pengobatan (Atman, 2007). Produktivitas kacang hijau di Indonesia mengalami fluktuasi setiap tahunnya. Data produksi Nasional (BPS, 2016) dalam 5 tahun terakhir dari 2011-2015 yaitu sebesar 1,148 t/ha, 1,16 t/ha, 1,124 t/ha, 1,176 t/ha, 1,183 t/ha, sedangkan untuk Provinsi NTT produksi kacang hijau termasuk rendah selama 5 tahun terakhir dari 2011-2015 yaitu 0,846 t/ha, $0,871 \mathrm{t} / \mathrm{ha}, 0,854 \mathrm{t} / \mathrm{ha}, 0,865 \mathrm{t} / \mathrm{ha}, 0,873 \mathrm{t} / \mathrm{ha}$ bila dibandingkan dengan provins lainnya. Produksi kacang hijau di Kabupaten Timor Tengah Utara (TTU) Dinas pertanian dalam 5 tahun terakhir 2012-2017 yaitu sebesar 0,899 t/ha, 0,893 t/ha $0,844 \mathrm{t} / \mathrm{ha}, 0,844 \mathrm{t} / \mathrm{ha}, 0,844 \mathrm{t} / \mathrm{ha}$

Penyebab rendahnya produksi kacang hijau di NTT disebabkan oleh beberapa faktor seperti rendahnya tingkat kesuburan tanah dan daya ikat ai tanah sehingga perlu teknologi sederhana untuk meningkatkan kesuburan tanah maupun kemampuan mengikat air. Salah satu upaya yang dapat dilakukan untuk memperbaiki kesuburan tanah adalah suplai unsur hara melalui pemberian biochar yang telah dikomposkan. Kompos biochar adalah campuran dari sisa-sisa bahan organik dengan bahan organik lain seperti pupuk kandang dan hijauan yang dicampur secara bersama-sama dan disiram dengan bakter mikroba pengurai untuk mempercepat proses dekomposisi. Ekebafe et al. (2015), menyatakan bahwa kompos biochar juga dapat beberapa kelebihan seperti meningkatkan kapasitas tukar kation dan $\mathrm{pH}$ tanah dan juga membangun kembali jaringan makanan dalam tanah dan menyediakan unsur hara bag tanaman, kompos biochar juga memiliki keunggulan lain seperti mengurang penggunaan biochar maupun pupuk. Kompos biochar juga meningkatkan afinitas serapan hara (Borchardet al., 2012).

Schulz et al., (2013) menambahkan pengaruh positif kompos biocha pada pertumbuhan tanaman dan sifat-sifat tanah menunjukkan bahwa pengomposan adalah cara yang baik untuk mengatasi kekurangan nutrisi yang ada didalam tanah sehingga bisa meningkatkan hasil produksi tanaman Beberapa hasil penelitian dengan menggunakan biochar diantaranya pada tanaman kacang yang menempati pot yang diberikan kompos biochar pupuk kandang sapi memberikan hasil berat biji per tanaman kacang hitam sebesar 15 20 g dan kacang kuning 15,88 g (Kolo, 2018), Kamlasi et al.,(2018) terhadap kacang mungo yang diberi perlakuan kompos padat daun gamal menghasilkan $0,3 \mathrm{t} / \mathrm{ha}$, dengan berat pertanaman sebesar $20,40 \mathrm{~g}$. sedangkan hasil penelitian Neonbeni \& Seran (2017), kacang hijau Fore Belu yang diberikan teh kompos dengan konsentrasi 1:5 menghasilkan 0,98 t/ha

Solusi yang dapat ditawarkan adalah biochar tidak langsung digunakan sebagai pembenah tanah in septisol semi arid, tetapi terlebih dahulu digunakan sebagai bahan pencampur seperti dedaunan hijau, kotoran ternak, dedak padi dan lain sebagainya dan dijadikan kompos biochar (bulking agent). Salah satu fungsi kompos biochar sebagai bulking agent dalam proses pengomposan adalah memperbaiki proses struktur tanah dan kualitas tanah (Dias et al., 2010). Perbaikan kualitas kompos ditandai dengan adanya peningkatan persentase yang dihasilkan. Selanjutnya dikatakan bahwa serbuk gergaji lebih efisien dalam menjaga bahan organik dan nitrogen dalam kompos matang. Aplikasi kompos biochar terbukti lebih efektif dalam meningkatkan sifat-sifat tanah dan hasil panen pada tanaman umur pendek dan tanaman umur panjang dibandingkan biochar saja (Agegnehuet al., 2017). Hasil penelitian Nur et al., (2014), menunjukkan bahwa aplikasi kompos biochar yang diperkaya meningkatkan hasil jagung BISI hybrid CV dan jagung umur genjah Madura pada dua musim berbeda yaitu baik musim hujan maupun musim kering pada tanah berkapur dalam tahun yang sama. Perbandingan dosis co-compost pupuk pertanian dapat meningkat hasil biji-bijian gandum (Qayyumet al., 2017). Dari uraian permasalah diatas maka perlu adanya penelitian mengenai "Pengaruh Jenis Kompos Biochar Terhadap Pertumbuhan dan Hasil Beberapa Kultivar Kacang Hijau",

Penelitian bertujuan untuk mengetahui respons kultivar kacang hijau terhadap aplikasi kompos biochar, mengetahui pengaruh takaran kompo biochar terhadap pertumbuhan dan hasil tanaman kacang hijau, mengetahui takaran kompos biochar terbaik terhadap pertumbuhan dan hasil tanaman kacang hijau, kacang kuning dan kacang hitam.

\section{Metode}

Penelitian ini dilaksanakan pada bulan Juli-September 2018 di kebun Fakultas Pertanian Universitas Timor Kelurahan Sasi, Kecamatan Kota Kefamenanu, Kabupaten TTU. Penelitian lapangan ini mengunakan Rancangan Acak Kelompok (RAK) faktorial $3 \times 3$ yang diulang 3 kali. Faktor pertama adalah takaran kompos biochar pupuk kandanag sapi yang terdiri dari 4 aras yakni kontrol 0 t/ha (B0), 10 t/ha (B1), 20 t/ha (B3), faktor kedua yaitu jenis kacang hijau terdiri, kacang hijau lokal Timor Fore Belu $\left(\mathrm{K}_{1}\right)$, kacang hitam $\left(\mathrm{K}_{2}\right)$ dan kacang kuning $\left(\mathrm{K}_{3}\right)$ dengan kombinasi perlakuan adalah $\mathrm{K}_{1} \mathrm{~B}_{0} \mathrm{~K}_{1} \mathrm{~B}_{1}$ $\mathrm{K}_{1} \mathrm{~B}_{3}, \mathrm{~K}_{2} \mathrm{~B}_{0}, \mathrm{~K}_{2} \mathrm{~B}_{1}, \mathrm{~K}_{2} \mathrm{~B}_{3}, \mathrm{~K}_{3} \mathrm{~B}_{0}, \mathrm{~K}_{3} \mathrm{~B}_{1}, \mathrm{~K}_{3} \mathrm{~B}_{3}$ yang diulang 3 kali sehingga terdapat 27 unit perlakuan.

Parameter yang diamati adalah parameter lingkungan, pertumbuhan dan hasil yakni $\mathrm{pH}$ dan DHL tanah, suhu tanah, tinggi tanaman, jumlah daun, diameter batang, luas daun, berat kering daun, berat kering tajuk, panjang akar, berat kering akar, bintil akar, berat kering berangkasan per tanaman, jumlah polong per tanaman, jumlah biji per polong, berta biji per polong, berat biji per tanaman, berat biji per petak, berat 100 biji, indeks panen. Data hasil pengamatan kemudian dianalisis dengan menggunakan sidik ragam (Anova) Rancangan Acak Kelompok (RAK). Rata-rata perlakuan selanjutnya diuji lanjut menggunakan Duncan Multiple Range Test (DMRT) dengan tingkat signifikan 5\% sesuai petunjuk Gomez dan Gomez (2010). Analisis data menggunakan program SAS 9,1

\section{Hasil dan Pembahasan \\ pH Tanah}

Hasil sidik ragam (Anova) menunjukkan tidak terjadi interaksi antara perlakuan jenis kacang hijau dan takaran kompos biochar terhadap parameter pengamatan $\mathrm{pH}$ tanah. Aras perlakuan jenis kacang maupun takaran kompos biochar tidak beda nyata antar aras perlakuan lainnya pada pengamatan $\mathrm{pH}$ tanah (Tabel 1). Penambahan kompos biochar pada lahan penelitian yang ditanami kacang hijau mampu meningkatkan $\mathrm{pH}$ tanah namun masih berada pada level normal. Hal ini mungkin disebabkan oleh biochar telah mengalami penurunan $\mathrm{pH}$ akibat proses pengomposan sehingga peningkatan $\mathrm{pH}$ didalam tanah tidak signifikan. Hasil penelitian Kolo (2018) mengungkapkan bahwa penambahan kompos biochar berbahan jenis kotoran ternak meningkatkan $\mathrm{pH}$ tanah tetapi tidak berbeda nyata dengan tanpa kompos biochar.

Tabel 1.pH Tanah

\begin{tabular}{clccccc}
\hline \multirow{2}{*}{$\begin{array}{c}\text { Waktu } \\
\text { Pengamatan }\end{array}$} & Jenis Kacang & \multicolumn{4}{c}{ Takaran Kompos Biochar (t/ha) } & \multirow{2}{*}{ Rerata } \\
\cline { 3 - 6 } & Hijau & $0(\mathrm{~B} 0)$ & $10(\mathrm{~B} 1)$ & $15(\mathrm{~B} 2)$ & $20(\mathrm{~B} 3)$ & \\
\hline \multirow{2}{*}{21} & Hijau (K1) & 6,44 & 6,58 & 6,62 & 6,51 & $6,54^{\text {a }}$ \\
& Hitam (K2) & 6,55 & 6,64 & 6,51 & 6,52 & $6,55^{\text {a }}$ \\
& Kuning (K3) & 6,44 & 6,54 & 6,63 & 6,67 & $6,57^{\text {a }}$ \\
\hline & Rerata & $6,48^{\text {a }}$ & $6,59^{\text {a }}$ & $6,59^{\text {a }}$ & $6,57^{\text {a }}$ & $(-)$ \\
\hline
\end{tabular}

Keterangan: Angka yang diikuti superscript pada baris dan kolom yang diikuti dengan huruf yang sama tidak berbeda nyata menurut uji DMRT $\alpha$ 5\%. ( - ): Tidak terjadi interaksi antar faktor

DHL Tanah 
Hasil sidik ragam (Anova) menunjukkan tidak terjadi interaksi antara perlakuan jenis kacang hijau dan takaran kompos biochar terhadap parameter pengamatan DHL tanah. Aras perlakuan jenis kacang maupun takaran kompos biochar menunjukkan tidak berbeda nyata dengan aras perlakuan lainnya (Tabe 2). Kompos biochar mampu meningkatkan DHL tanah karena adanya adanya penambahan jenis dan jumlah mineral yang diperoleh dari penambahan biochar maupun bahan dasar pembuatan kompos. Berek et al.,(2017) bahwa peningkatan DHL tanah disebabkan oleh penambahan kation-kation kedalam tanah yang berasal dari biochar maupun dari kompos teh.

\begin{tabular}{lllllll}
\multicolumn{2}{l}{ Tabel 2. DHL Tanah } \\
\hline \multirow{2}{*}{$\begin{array}{c}\text { Waktu } \\
\text { Pengamatan }\end{array}$} & Jenis Kacang & \multicolumn{6}{c}{ Takaran Kompos Biochar (t/ha) } & \multirow{2}{*}{ Rerata } \\
\cline { 3 - 6 } 21 & Hijau & $0(\mathrm{~B} 0)$ & $10(\mathrm{~B} 1)$ & $15(\mathrm{~B} 2)$ & $20(\mathrm{~B} 3)$ & \\
\hline \multirow{2}{*}{21} & Hijau (K1) & 420,50 & 460,67 & 410,67 & 548,00 & $463,55^{\mathrm{a}}$ \\
& Hitam (K2) & 397,00 & 469,33 & 418,00 & 481,33 & $441,42^{\mathrm{a}}$ \\
& Kuning (K3) & 413,00 & 480,00 & 504,67 & 500,33 & $474,50^{\mathrm{a}}$ \\
\hline & Rerata & $408,88^{\text {a }}$ & $470,00^{\text {a }}$ & $444,44^{\text {a }}$ & $509,89^{\text {a }}$ & $(-)$ \\
\hline
\end{tabular}

Keterangan: Angka yang diikuti superscript pada baris dan kolom yang diikuti dengan huruf yang sama tidak berbeda nyata menurut uji DMRT a 5\%.( - ): Tidak terjadi interaksi antar faktor.

\section{Suhu Tanah $\left({ }^{\circ} \mathrm{C}\right)$}

Hasil sidik ragam (Anova) menunjukkan tidak terjadi interaksi antara perlakuan jenis kacang hijau dan takaran kompos biochar terhadap parameter pengamatan suhu tanah. Aras perlakuan jenis kacang tidak berbeda nyata sedangkan pada perlakuan takaran kompos biochar terjadi beda nyata dengan perlakuan kompos biochar 15 t/ha menghasilkan suhu paling tinggi yang berbeda nyata dengan perlakuan lainnya (Tabel 3). Suhu tanah yang dihasilkan dalam penelitian ini masih berada ada pada taraf normal dari syarat tumbuh tanaman kacang hijau sehingga suhu tanah sebagai faktor pendukung pertumbuhan dan perkembangan tanaman kacang hijau.

\section{Tabel 3. Suhu Tanah $\left({ }^{\circ} \mathrm{C}\right)$}

\begin{tabular}{|c|c|c|c|c|c|c|}
\hline \multirow{2}{*}{$\begin{array}{c}\text { Waktu } \\
\text { Pengamatan }\end{array}$} & \multirow{2}{*}{$\begin{array}{c}\text { Jenis Kacang } \\
\text { Hijau } \\
\end{array}$} & \multicolumn{4}{|c|}{ Takaran Kompos Biochar (t/ha) } & \multirow{2}{*}{ Rerata } \\
\hline & & $0(\mathrm{~B} 0)$ & $10(\mathrm{~B} 1)$ & $15(\mathrm{~B} 2)$ & $20(\mathrm{~B} 3)$ & \\
\hline \multirow{4}{*}{21} & Hijau (K1) & 26,55 & 25,13 & 27,13 & 25,50 & $26.03^{\mathrm{a}}$ \\
\hline & $\operatorname{Hitam}(\mathrm{K} 2)$ & 25,30 & 25,46 & 27,16 & 26,40 & $26.08^{\mathrm{a}}$ \\
\hline & Kuning (K3) & 26,36 & 26,30 & 26,93 & 26,10 & $26.42^{\mathrm{a}}$ \\
\hline & Rerata & $26,01^{\mathrm{b}}$ & $25,63^{\mathrm{b}}$ & $27,07^{\mathrm{a}}$ & $26,00^{\mathrm{b}}$ & $(-)$ \\
\hline
\end{tabular}

Keterangan: Angka yang diikuti super script pada baris dan kolom yang diikuti dengan huruf yang sama tidak berbeda nyata menurut uji DMRT a 5\%.( - ): Tidak terjadi interaksi antar faktor.

\section{Tinggi Tanaman $(\mathrm{cm})$}

Hasil sidik ragam (Anova) menunjukkan tidak terjadi interaksi antara perlakuan jenis kacang hijau dan takaran kompos biochar terhadap parameter pengamatan tinggi tanaman. Aras perlakuan jenis kacang berbeda nyata pada saat tanaman kacang berumur 14 hst dengan tanaman tertinggi dihasilkan oleh jenis kacang kuning yang berbeda nyata dengan jenis kacang hijau tetapi pada pengamatan selanjutnya tidak berbeda nyata. Takaran kompos biochar menunjukkan bahwa tidak berbeda nyata pada semua waktu pengamatan kecuali pada saat pengamatan 21 hst yang menunjukkan beda nyata dengan yang mana perlakuan takaran kompos biochar 20 t/ha menghasilkan tinggi tanaman paling tinggi yang berbeda sangat nyata dengan tanpa kompos biochar (Tabel 4). Seragamnya tinggi tanaman sangat mungkin diakibatkan oleh $\mathrm{pH}$, DHL dan suhu tanah yang cocok dan sesuai dengan syarat tumbuh tanaman kacang hijau yang merupakan konversi dari kompos yang diberikan pada tanah.

Tabel 4. Tinggi Tanaman $(\mathrm{cm})$

\begin{tabular}{|c|c|c|c|c|c|c|}
\hline \multirow{2}{*}{$\begin{array}{c}\text { Waktu } \\
\text { Pengamatan } \\
\text { HST }\end{array}$} & \multirow{2}{*}{$\begin{array}{c}\text { Jenis Kacang } \\
\text { Hijau }\end{array}$} & \multicolumn{4}{|c|}{ Takaran Kompos Biochar (t/ha) } & \multirow{2}{*}{ Rerata } \\
\hline & & $0(\mathrm{~B} 0)$ & $10(\mathrm{~B} 1)$ & $15(\mathrm{~B} 2)$ & $20(\mathrm{~B} 3)$ & \\
\hline \multirow{4}{*}{14} & Hijau (K1) & 9,76 & 10,48 & 12,44 & 11,58 & $11.35^{b}$ \\
\hline & Hitam (K2) & 11,64 & 12,53 & 11,74 & 12,42 & $12.08^{a b}$ \\
\hline & Kuning (K3) & 12,89 & 12,55 & 12,73 & 13,43 & $12.90^{\mathrm{a}}$ \\
\hline & Rerata & $11,64^{\mathrm{a}}$ & $11,97^{a}$ & $12,30^{\mathrm{a}}$ & $12,57^{\mathrm{a}}$ & $(-)$ \\
\hline \multirow{4}{*}{21} & Hijau (K1) & 11,66 & 13,04 & 14,18 & 16,04 & $13.92^{\mathrm{a}}$ \\
\hline & Hitam (K2) & 14,55 & 14,80 & 14,53 & 13,48 & $14.34^{\mathrm{a}}$ \\
\hline & Kuning (K3) & 14,76 & 13,41 & 15,72 & 16,29 & $15.04^{\mathrm{a}}$ \\
\hline & Rerata & $13,90^{\mathrm{b}}$ & $13,75^{\mathrm{b}}$ & $14,81^{\mathrm{ab}}$ & $15,27^{\mathrm{a}}$ & $(+)$ \\
\hline \multirow{4}{*}{28} & Hijau (K1) & 14,41 & 15,46 & 17,35 & 20,88 & $17.26^{\mathrm{a}}$ \\
\hline & Hitam (K2) & 17,25 & 18,51 & 18,79 & 16,35 & $17.72^{\mathrm{a}}$ \\
\hline & Kuning (K3) & 18,30 & 14,22 & 21,62 & 20,80 & $18.73^{\mathrm{a}}$ \\
\hline & Rerata & $16,93^{\mathrm{ab}}$ & $16,06^{\mathrm{b}}$ & $19,25^{\mathrm{a}}$ & $19,35^{\mathrm{a}}$ & $(-)$ \\
\hline \multirow{4}{*}{42} & Hijau (K1) & 18,28 & 19,37 & 25,76 & 29,25 & $23.61^{\mathrm{a}}$ \\
\hline & Hitam (K2) & 21,64 & 23,35 & 26,39 & 20,00 & $22.84^{\mathrm{a}}$ \\
\hline & Kuning (K3) & 22,52 & 20,14 & 26,07 & 28,21 & $24.23^{\mathrm{a}}$ \\
\hline & Rerata & $21,13^{\mathrm{a}}$ & $20,95^{\mathrm{a}}$ & $26,07^{\mathrm{a}}$ & $25,82^{\mathrm{a}}$ & $(-)$ \\
\hline
\end{tabular}

Keterangan: Angka yang diikuti superscript pada baris dan kolom yang diikuti dengan huruf yang sama tidak berbeda nyata menurut uji DMRT $\alpha$ 5\%. (-): Tidak terjadi interaksi antar faktor.

\section{Jumlah Daun (Helai)}

Hasil sidik ragam (Anova) menunjukkan tidak terjadi interaksi antara perlakuan jenis kacang hijau dan takaran kompos biochar terhadap parameter pengamatan jumlah daun.

$\underline{\text { Tabel 5. Jumlah Daun (Helai) }}$

\begin{tabular}{|c|c|c|c|c|c|c|}
\hline \multirow{2}{*}{$\begin{array}{c}\text { Waktu } \\
\text { Pengamatan } \\
\text { HST }\end{array}$} & \multirow{2}{*}{$\begin{array}{c}\text { Jenis Kacang } \\
\text { Hijau }\end{array}$} & \multicolumn{4}{|c|}{ Takaran Kompos Biochar (t/ha) } & \multirow{2}{*}{ Rerata } \\
\hline & & $0(\mathrm{~B} 0)$ & $10(\mathrm{~B} 1)$ & $15(\mathrm{~B} 2)$ & $20(\mathrm{~B} 3)$ & \\
\hline \multirow{4}{*}{14} & Hijau (K1) & 2,00 & 2,00 & 2,00 & 2,00 & $2.00^{\mathrm{b}}$ \\
\hline & Hitam (K2) & 2,00 & 2,00 & 2,00 & 2,11 & $2.02^{b}$ \\
\hline & Kuning (K3) & 2,33 & 2,00 & 2,33 & 2,44 & $2.27^{\mathrm{a}}$ \\
\hline & Rerata & $2,12^{\mathrm{a}}$ & $2,00^{\mathrm{a}}$ & $2,11^{\mathrm{a}}$ & $2,18^{\mathrm{a}}$ & $(-)$ \\
\hline \multirow{4}{*}{21} & Hijau (K1) & 5,00 & 4,66 & 4,16 & 5,00 & $4.68^{\mathrm{a}}$ \\
\hline & Hitam (K2) & 3,83 & 3,33 & 4,33 & 3,58 & $3.77^{\mathrm{b}}$ \\
\hline & Kuning (K3) & 4,00 & 2,83 & 4,83 & 4,38 & $4.01^{\mathrm{ab}}$ \\
\hline & Rerata & $4,18^{\mathrm{a}}$ & $3,61^{\mathrm{a}}$ & $4,44^{\mathrm{a}}$ & $4,32^{\mathrm{a}}$ & $(-)$ \\
\hline \multirow{4}{*}{28} & Hijau (K1) & 6,25 & 6,16 & 6,05 & 8,44 & $6,77^{a}$ \\
\hline & Hitam (K2) & 5,50 & 6,27 & 6,89 & 5,50 & $6,04^{\mathrm{a}}$ \\
\hline & Kuning (K3) & 6,16 & 4,61 & 7,55 & 7,22 & $6,39^{\mathrm{a}}$ \\
\hline & Rerata & $5,93^{\mathrm{a}}$ & $5,68^{a}$ & $6,83^{a}$ & $7,05^{\mathrm{a}}$ & $(-)$ \\
\hline \multirow{4}{*}{42} & Hijau (K1) & 10,55 & 10,61 & 13,83 & 15,05 & $12,69^{\mathrm{a}}$ \\
\hline & Hitam (K2) & 10,66 & 12,61 & 14,70 & 11,27 & $12,31^{\mathrm{a}}$ \\
\hline & Kuning (K3) & 10,66 & 11,16 & 14,67 & 13,04 & $12,38^{\mathrm{a}}$ \\
\hline & Rerata & $10,63^{\mathrm{b}}$ & $11,42 \mathrm{~b}$ & $14,40^{\mathrm{a}}$ & $13,12^{\mathrm{ab}}$ & $(-)$ \\
\hline
\end{tabular}

Keterangan: Angka yang diikuti superscript pada baris dan kolom yang diikuti dengan huruf yang sama tidak berbeda nyata menurut uji DMRT \& $5 \% .(-)$ : Tidak terjadi interaksi antar faktor.

Perlakuan takaran kompos menghasilkan jumlah daun tidak berbeda nyata antar aras perlakuan pada semua waktu pengamatan kecuali pada waktu pengamatan 42 hst sedangkan pada perlakuan jenis kacang terjadi beda nyata pada waktu pengamatan 14 dan 21 hst tetapi tidak berbeda nyata pada waktu pengamatan 28 dan 42 hst (Tabel 5). Hasil penelitian ini menunjukkan bahwa kompos biochar sangat mempengaruhi pertumbuhan tanaman kacang hijau terutama pada proses pembentukkan sel-sel baru pada batang yang semakin tinggi sebagai tempat pembentukkan daun-daun baru sehingga jumlah daun terus bertambah karena pada batang akan muncul ruas-ruas baru tempat melekatnya daun (Soediarto et al., 1992). Pertumbuhan awal tanaman kacang pada semua cultivar hampir seragam. Seragamnya jumlah daun semua kultivar kacang hijau sangat mungkin diakibatkan oleh pH, DHL dan suhu tanah yang cocok dan sesuai dengan syarat tumbuh tanaman kacang hijau yang merupakan konversi dari kompos yang diberikan pada tanah.

\section{Diameter Batang (mm)}

Hasil sidik ragam (Anova) menunjukkan tidak terjadi interaksi antara perlakuan jenis kacang hijau dan takaran kompos biochar terhadap parameter pengamatan diameter batang. Perlakuan jenis kacang hijau tidak berbeda nyata antar aras perlakuan sedangkan pada perlakuan takaran kompos biochar $15 \mathrm{t} / \mathrm{ha}$ menghasilkan diameter batang yang lebih besar dan berbeda nyata dengan aras lainnya kecuali dengan aras perlakuan 20 t/ha (Tabel 6). Bertambahnya ukuran batang tanaman dipengaruhi oleh jenis kacang dan disebabkan juga oleh jumlah unsur hara yang terkandung didalam tanah lebih banyak dibandingkan dengan tanaman kacang yang tidak diberikan kompos biochar. Hal ini dibuktikan dengan nilai DHL tanah pada perlakuan penggunaan kompos biochar lebih tinggi nilainya dibandingkan dengan tanpa kompos biochar.

Tabel 6. Diameter Batang (mm)

\begin{tabular}{clccccc}
\multirow{2}{*}{$\begin{array}{c}\text { Waktu } \\
\text { Pengamatan } \\
\text { HST }\end{array}$} & $\begin{array}{c}\text { Jenis Kacang } \\
\text { Hijau }\end{array}$ & \multicolumn{4}{c}{ Takaran Kompos Biochar (t/ha) } & \\
& Hijau (K1) & 10,55 & 10,61 & 13,83 & 15,05 & $12.69^{\mathrm{a}}$ \\
& Kitam (K2) & 10,66 & 12,61 & 14,70 & 11,27 & $12.31^{\mathrm{a}}$ \\
& Hentrol (B0) & $10(\mathrm{~B} 1)$ & $15(\mathrm{~B} 2)$ & $20(\mathrm{~B} 3)$ & Rerata \\
& Kuning (K3) & 10,66 & 11,16 & 14,67 & 13,04 & $13.38^{\mathrm{a}}$ \\
\cline { 2 - 6 } & Rerata & $10,63^{\mathrm{b}}$ & $11,46^{\mathrm{b}}$ & $14,40^{\mathrm{a}}$ & $13,12^{\mathrm{a}}$ & $(-)$ \\
\hline
\end{tabular}

Keterangan: Angka yang diikuti superscript pada baris dan kolom yang diikuti dengan huruf yang sama tidak berbeda nyata menurut uji DMRT a 5\%. ( - ): Tidak terjadi interaksi antar faktor.

\section{Luas Daun $\left(\mathrm{cm}^{2}\right)$}

Hasil Penelitian menunjukkan bahwa tidak terjadi interaksi antara perlakuan takaran kompos biochar dan beberapa kultivar kacang hijau terhadap parameter pengamatan luas daun. Takaran biochar menunjukkan bahwa terjadi beda nyata antar aras perlakuan pada pengamatan 35 hst dan tidak berbeda nyata pada pengamatan 50 hst sedangkan pada jenis kacang tidak terjadi beda nyata antar aras perlakuan baik pada pengamatan 35 maupun pengamatan 50 hst (Tabel 7). Tanaman kacang yang diberikan kompos biochar memeiliki daun yang lebih luas dibandingkan dengan tanaman yang tidak diberikan kompos biochar. Luas daun yang diamati mengalami peningkatan secara sigmoid mengikuti umur tanaman yang berarti daun tanaman semakin luas seiring dengan waktu yang dibutuhkan oleh tanaman untuk tumbuh dan berkembang (Sitompul \& Guritno, 1995). 
Tabel 7. Luas Daun $\left(\mathrm{cm}^{2}\right)$

\begin{tabular}{clccccc}
\hline \multirow{2}{*}{$\begin{array}{c}\text { Waktu } \\
\text { Pengamatan } \\
\text { HST }\end{array}$} & $\begin{array}{c}\text { Jenis Kacang } \\
\text { Hijau }\end{array}$ & $\begin{array}{c}\text { Kontrol } \\
\text { (B0) }\end{array}$ & $10(\mathrm{~B} 1)$ & $15(\mathrm{~B} 2)$ & $20(\mathrm{~B} 3)$ & \\
\hline \multirow{3}{*}{35} & Hijau (K1) & 5775 & 12888 & 20593 & 21986 & $15310 \mathrm{a}$ \\
& Hitam (K2) & 1335 & 17307 & 21169 & 13748 & $13390 \mathrm{a}$ \\
& Kuning (K3) & 7363 & 19994 & 14656 & 23274 & $16321 \mathrm{a}$ \\
\cline { 3 - 6 } & Rerata & $4824 \mathrm{~b}$ & 16729 a & 18806 a & $19669 \mathrm{a}$ & $(-)$ \\
\hline \multirow{5}{*}{50} & Hijau (K1) & 7972 & 15000 & 30198 & 36671 & $22460 \mathrm{a}$ \\
& Hitam (K2) & 10532 & 46736 & 36312 & 22848 & 29109 a \\
& Kuning (K3) & 30332 & 32212 & 39578 & 38072 & 35048 a \\
\cline { 2 - 5 } & Rerata & 16279 a & 31316 a & 35362 a & 32530 a & $(-)$ \\
\hline
\end{tabular}

Keterangan: Angka yang diikuti superscript pada baris dan kolom yang diikuti dengan huruf yang sama tidak berbeda nyata menurut uji DMRT $\alpha .5 \%$. (-): Tidak terjadi interaksi antar faktor.

\section{Berat Kering Daun (Kg)}

Hasil sidik ragam (Anova) menunjukkan tidak terjadi interaksi antara perlakuan jenis kacang hijau dan takaran kompos biochar terhadap parameter pengamatan berat kering daun. Aras perlakuan kultivar kacang hijau menunjukkan tidak berbeda nyata pada semua waktu pengamatan sedangkan pada takaran kompos biochar berbeda nyata pada saat tanaman berumur $35 \mathrm{hst}$ tetapi tidak berbeda nyata pada saat 50 hst (Tabel 8). Berat kering daun kacang pada tanaman yang diberikan kompos biochar lebih berat. Hal ini sebagai akibat konversi nutrisi tanaman cukup tersedia didalam tanah yang menyebabkan komponen-komponen fotosintetis didalam daun lebih banyak dan lebih rapat (Sitompul dan Guritno, 1995).

$\frac{\text { Tabel 8. Berat Kering Daun }(\mathrm{Kg})}{\text { Waktu }}$

\begin{tabular}{|c|c|c|c|c|c|c|}
\hline \multirow{2}{*}{$\begin{array}{c}\text { Waktu } \\
\text { Pengamatan } \\
\text { HST }\end{array}$} & \multirow[b]{2}{*}{$\begin{array}{c}\text { Jenis Kacang } \\
\text { Hijau }\end{array}$} & \multicolumn{4}{|c|}{ Takaran Kompos Biochar (t/ha) } & \multirow[b]{2}{*}{ Rerata } \\
\hline & & $\begin{array}{c}\text { Kontrol } \\
\text { (B0) }\end{array}$ & $\begin{array}{c}10 \\
\text { (B1) }\end{array}$ & $\begin{array}{c}15 \\
\text { (B2) }\end{array}$ & $\begin{array}{c}20 \\
\text { (B3) }\end{array}$ & \\
\hline \multirow{4}{*}{35} & Hijau (K1) & 0,22 & 0,15 & 0,33 & 0,12 & $0.20^{\mathrm{a}}$ \\
\hline & Hitam (K2) & 0,17 & 0,21 & 0,45 & 0,14 & $0.24^{\mathrm{a}}$ \\
\hline & Kuning (K3) & 0,24 & 0,28 & 0,24 & 0,18 & $0.23^{\mathrm{a}}$ \\
\hline & Rerata & $0,21^{\mathrm{ab}}$ & $0,21^{\mathrm{ab}}$ & $0,34^{\mathrm{a}}$ & $0,15^{\mathrm{b}}$ & $(-)$ \\
\hline \multirow{4}{*}{50} & Hijau (K1) & 0,23 & 0,32 & 0,46 & 0,23 & $0.32^{\mathrm{a}}$ \\
\hline & Hitam (K2) & 0,15 & 0,52 & 0,57 & 0,28 & $0.38^{\mathrm{a}}$ \\
\hline & Kuning (K3) & 0,55 & 0,47 & 0,62 & 0,49 & $0.53^{\mathrm{a}}$ \\
\hline & Rerata & $0,32^{\mathrm{a}}$ & $0,44^{\mathrm{a}}$ & $0,55^{\mathrm{a}}$ & $0,35^{\mathrm{a}}$ & $(-)$ \\
\hline
\end{tabular}

Keterangan: Angka yang diikuti superscript pada baris dan kolom yang diikuti dengan huruf yang sama tidak berbeda nyata menurut uji DMRT a 5\%.( - ): Tidak terjadi interaksi antar faktor.

\section{Panjang Akar (cm)}

Hasil sidik ragam (Anova) menunjukkan terjadi interaksi antara perlakuan jenis kacang hijau dan takaran kompos biochar terhadap parameter pengamatan panjang akar 35 hst tetapi tidak terjadi interaksi pada 50 hst. Akar terpanjang pada pengamatan 35 hst diperoleh pada kombinasi perlakuan takaran kompos biochar 15 t/ha dengan jenis kacang hijau fore Belu yang berbeda sangat nyata dengan kombinasi perlakuan lainnya. Tidak terjadi beda nyata pada aras perlakuan takaran kompos biochar maupun jenis kacang hijau pada pengamatan 50 hst. Aras perlakuan jenis kacang tidak berbeda nyata sedangkan aras perlakuan takaran kompos biochar menunjukkan beda nyata dengan akar paling panjang dihasilkan oleh takaran kompos biochar $20 \mathrm{t} / \mathrm{ha}$ yang berbeda nyata dengan tanpa kompos biochar (Tabel 9). Secara keseluruhan perlakuan tanpa kompos biochar menghasilkan panjang akar paling pendek dibandingkan dengan perlakuan kompos biochar. Hal ini mungkin diakibatkan oleh tanah yang diberikan kompos biochar lebih remah dan lebih ringan sehingga perakaran tanaman kacang lebih leluasa menerobos tanah untuk mendapatkan air dan unsur hara dibandikan yang kontrol yang kemungkinan tanahnya lebih padat sehingga perakaran tanaman terhambat.

Tabel 9. Panjang Akar (cm)

\begin{tabular}{|c|c|c|c|c|c|c|}
\hline \multirow{2}{*}{$\begin{array}{c}\text { Waktu } \\
\text { Pengamatan } \\
\text { HST } \\
\end{array}$} & \multirow{2}{*}{$\begin{array}{c}\text { Jenis Kacang } \\
\text { Hijau }\end{array}$} & \multicolumn{4}{|c|}{ Takaran Kompos Biochar (t/ha) } & \multirow[b]{2}{*}{ Rerata } \\
\hline & & $\begin{array}{c}\text { Kontrol } \\
\text { (B0) }\end{array}$ & $10(\mathrm{~B} 1)$ & $15(\mathrm{~B} 2)$ & 20 (B3) & \\
\hline \multirow{4}{*}{35} & Hijau (K1) & $13,58 \mathrm{c}$ & $13,20 \mathrm{c}$ & $24,06 \mathrm{a}$ & $17,83 \mathrm{bc}$ & 17,17 \\
\hline & Hitam (K2) & $15,15 \mathrm{bc}$ & $15,13 \mathrm{bc}$ & $15,63 \mathrm{bc}$ & $19,13 \mathrm{~b}$ & 16,26 \\
\hline & Kuning (K3) & $15,53 \mathrm{bc}$ & $16,00 \mathrm{bc}$ & $15,60 \mathrm{bc}$ & $18,13 \mathrm{bc}$ & 16,31 \\
\hline & Rerata & 14,75 & 14,77 & 18,43 & 18,36 & $(+)$ \\
\hline \multirow{4}{*}{50} & Hijau (K1) & 15,50 & 17,83 & 32,33 & 43,00 & $28.22^{\mathrm{a}}$ \\
\hline & Hitam (K2) & 12,50 & 16,83 & 21,83 & 20,50 & $17.91^{\mathrm{a}}$ \\
\hline & Kuning (K3) & 21,67 & 26,33 & 27,17 & 31,83 & $26.75^{a}$ \\
\hline & Rerata & $16,68^{\mathrm{b}}$ & $20,33^{a b}$ & $27,11^{\mathrm{ab}}$ & $31,77^{\mathrm{a}}$ & $(-)$ \\
\hline
\end{tabular}

Keterangan: Angka yang diikuti superscript pada baris dan kolom yang diikuti dengan huruf yang sama tidak berbeda nyata menurut uji DMRT $\alpha$ 5\%.( - ): Tidak terjadi interaksi antar faktor.

\section{Berat Kering Akar (g)}

Hasil penelitian menunjukkan bahwa tidak terjadi interaksi antara perlakuan takaran kompos biochar dengan kultivar kacang hijau.
Tabel 10. Berat Kering Akar (g)

\begin{tabular}{|c|c|c|c|c|c|c|}
\hline \multirow{2}{*}{$\begin{array}{c}\text { Waktu } \\
\text { Pengamatan } \\
\text { HST }\end{array}$} & \multirow{2}{*}{$\begin{array}{c}\text { Jenis Kacang- } \\
\text { Hijau }\end{array}$} & \multicolumn{4}{|c|}{ Takaran Kompos Biochar (t/ha) } & \multirow[b]{2}{*}{ Rerata } \\
\hline & & Kontrol (B0) & $10(\mathrm{~B} 1)$ & 15 (B2) & 20 (B3) & \\
\hline \multirow{4}{*}{35} & Hijau (K1) & 0,06 & 0,08 & 0,12 & 0,07 & $0,08^{\mathrm{b}}$ \\
\hline & $\operatorname{Hitam}(\mathrm{K} 2)$ & 0,05 & 0,16 & 0,13 & 0,10 & $0,11^{\mathrm{ab}}$ \\
\hline & Kuning (K3) & 0,13 & 0,15 & 0,15 & 0,13 & $0,14^{\mathrm{a}}$ \\
\hline & Rerata & $0,08 \mathrm{a}$ & $0,13 \mathrm{a}$ & $0,13 \mathrm{a}$ & $0,10 \mathrm{a}$ & $(-)$ \\
\hline \multirow{4}{*}{50} & Hijau (K1) & 0,18 & 0,15 & 0,33 & 0,12 & $0,19^{a}$ \\
\hline & Hitam (K2) & 0,17 & 0,21 & 0,45 & 0,14 & $0,24^{\mathrm{a}}$ \\
\hline & Kuning (K3) & 0,24 & 0,28 & 0,24 & 0,18 & $0,23^{\mathrm{a}}$ \\
\hline & Rerata & $0,20^{\mathrm{b}}$ & $0,21^{\mathrm{ab}}$ & $0,34^{\mathrm{a}}$ & $0,15^{\mathrm{b}}$ & $(-)$ \\
\hline
\end{tabular}

Keterangan: Angka yang diikuti superscript pada baris dan kolom yang diikuti dengan huruf yang sama tidak berbeda nyata menurut uji DMRT $\alpha$ 5\%. (-): Tidak terjadi interaksi antar faktor

Jenis kacang hijau menunjukkan beda nyata pada pengamatan 35 hst dengan berat kering akar paling berat dihasilkan oleh jenis kacang kuning yang berbeda sangat nyata dengan kacang hijau, sedangkan pada pengamatan 50 hst tidak terjadi beda nyata. Perlakuan takaran kompos biochar pada pengamatan 35 hst tidak terjadi beda nyata antara aras perlakuan tetapi pada pengamatan 50 hst terjadi beda nyata yang mana kompos biochar 15 t/ha menghasilkan berat kering akar paling tinggi yang berbeda sangat nyata dengan perlakuan takaran kompos biochar $20 \mathrm{t} / \mathrm{ha}$ (Tabel 10). Tingginya berat kering akar pada perlakuan takaran kompos biochar 15 t/ha diakibatkan oleh panjang akar yang lebih pendek dan mungkin memiliki jumlah yang lebih banyak dengan ukuran akar lebih besar menyebabkan akumulasi berat akar lebih tinggi.

\section{Total Bintil Akar}

Hasil sidik ragam (Anova) menunjukkan tidak terjadi interaksi antara perlakuan jenis kacang hijau dan takaran kompos biochar terhadap parameter pengamatan total bintil akar 35 hst tetapi terjadi interaksi pada 50 hst. Perlakuan jenis kacang hijau pada saat tanaman berumur 35 hst menunjukkan adanya beda nyata dengan jenis kacang hijau Fore Belu lebih banyak menghasilkan bintil akar yang berbeda nyata dengan kacang hitam sedangkan takaran kompos biochar 20 t/ha menghasilkan jumlah bintil akar paling banyak yang berbeda sangat nyata dengan kontrol (Tabel 11). Jumlah bintil akar paling banyak dihasilkan oleh kombinasi perlakuan jenis kacang hijau Fore Belu dengan kacang hijau Fore Belu yang berbeda sangat nyata dengan kacang hijau Fore Belu tanpa kompos biochar. Perlakuan takaran kompos biochar cenderung menghasilkan bintil akar lebih banyak dari pada kontrol. Hal ini mungkin diakibatkan oleh populasi bakteri azobactear pada kompos lebih banyak pada saat pembuatan kompos biochar sedangkan jenis Fore Belu lebih banyak menghasilkan bintil akar yang mungkin diakibatkan oleh sistem adaptasinya lebih baik dengan tanah dibandingkan jenis kacang lainnya.

$\underline{\text { Tabel 11.Total Bintil Akar }}$

\begin{tabular}{|c|c|c|c|c|c|c|}
\hline \multirow{2}{*}{$\begin{array}{c}\text { Waktu } \\
\text { Pengamatan } \\
\text { HST }\end{array}$} & \multirow[b]{2}{*}{$\begin{array}{c}\text { Jenis Kacang } \\
\text { Hijau }\end{array}$} & \multicolumn{4}{|c|}{ Takaran Kompos Biochar (t/ha) } & \multirow[b]{2}{*}{ Rerata } \\
\hline & & $\begin{array}{c}\text { Kontrol } \\
\text { (B0) }\end{array}$ & $10(\mathrm{~B} 1)$ & $15(\mathrm{~B} 2)$ & $20(\mathrm{~B} 3)$ & \\
\hline \multirow{4}{*}{35} & Hijau (K1) & 14,83 & 19,16 & 37,66 & 29,83 & $25,35^{\mathrm{a}}$ \\
\hline & Hitam (K2) & 21.00 & 19,66 & 27,83 & 22,66 & $22,79^{b}$ \\
\hline & Kuning (K3) & 18,83 & 22.83 & 24,00 & 28,66 & $23,58^{\mathrm{ab}}$ \\
\hline & Rerata & $18,22^{\mathrm{b}}$ & $20,55^{b}$ & $29,83^{\mathrm{a}}$ & $27,05^{\mathrm{a}}$ & $(-)$ \\
\hline \multirow{4}{*}{50} & Hijau (K1) & $17,67 \mathrm{~b}$ & $20,67 \mathrm{ab}$ & $34,67 \mathrm{ab}$ & $46,83 \mathrm{a}$ & $29,95^{\mathrm{a}}$ \\
\hline & Hitam (K2) & $14,50 \mathrm{~b}$ & $19,33 \mathrm{ab}$ & $22,67 \mathrm{ab}$ & $21,50 \mathrm{ab}$ & $19,50^{\mathrm{a}}$ \\
\hline & Kuning (K3) & $22,83 \mathrm{ab}$ & $27,67 \mathrm{ab}$ & $32,50 \mathrm{ab}$ & $32,33 \mathrm{ab}$ & $28,83^{\mathrm{a}}$ \\
\hline & Rerata & $18,33 \mathrm{~b}$ & $22,55 \mathrm{ab}$ & $29,94 \mathrm{ab}$ & $33,55 \mathrm{a}$ & $(+)$ \\
\hline
\end{tabular}

Keterangan: Angka yang diikuti superscript pada baris dan kolom yang diikuti dengan huruf yang sama tidak berbeda nyata menurut uji DMRT a 5\%.( - ): Tidak terjadi interaksi antar faktor.

\section{Bintil Akar Efektif}

Hasil sidik ragam (Anova) menunjukkan tidak terjadi interaksi antara perlakuan jenis kacang hijau dan takaran kompos biochar terhadap parameter pengamatan bintil akar efektif. Aras perlakuan jenis kacang hijau menunjukkan bahwa tidak terjadi beda nyata pada saat pengamatan 35 maupun 50 hst, sedangkan perlakuan takaran kompos biochar menunjukkan beda nyata antar perlakuan yang berbeda sangat nyata dengan tanpa kompos biochar pada semua waktu pengamatan (Tabel 12)

\section{Berat Kering Total}

Hasil sidik ragam (Anova) menunjukkan tidak terjadi interaksi antara perlakuan jenis kacang hijau dan takaran kompos biochar terhadap parameter pengamatan berat kering total. Aras perlakuan jenis kacang menunjukkan tidak terjadi beda nyata antar aras perlakuan baik pada pengamatan 35 maupun $50 \mathrm{hst}$ sedangkan pada perlakuan takaran kompos biochar tidak terjadi beda nyata pada pengamatan 35 hst tetapi berbeda nyata pada pengamatan 50 hst dengan berat kering total tanaman paling tinggi dihasilkan oleh takaran kompos biochar 15 t/ha yang berbeda nyata takaran kompos biochar 20t/ha (Tabel 13). Hal ini mungkin diakibatkan oleh konversi hara lebih banyak diarahkan untuk pertumbuhan vegetatif sehingga tajuk tanaman lebih subur. 
Tabel 12. Bintil Akar Efektif

\begin{tabular}{clccccc}
\hline \multirow{2}{*}{$\begin{array}{c}\text { Waktu } \\
\text { Pengamatan } \\
\text { HST }\end{array}$} & Jenis Kacang & \multicolumn{6}{c}{ Takaran Kompos Biochar (t/ha) } & \\
\cline { 3 - 6 } & Hijau & $\begin{array}{c}\text { Kontrol } \\
(\mathrm{B} 0)\end{array}$ & $10(\mathrm{~B} 1)$ & $15(\mathrm{~B} 2)$ & $20(\mathrm{~B} 3)$ & \\
\hline \multirow{3}{*}{35} & Hijau (K1) & 13,67 & 17,00 & 37,66 & 28,16 & $24,12^{\mathrm{a}}$ \\
& Hitam (K2) & 19,50 & 16,50 & 27,50 & 22,50 & $21,50^{\mathrm{a}}$ \\
& Kuning (K3) & 18,50 & 22,50 & 22,83 & 27,83 & $22,91^{\mathrm{a}}$ \\
\cline { 2 - 6 } & Rerata & $17,22^{\mathrm{b}}$ & $18,66^{\mathrm{ab}}$ & $29,33^{\mathrm{a}}$ & $26,16^{\text {ab }}$ & $(-)$ \\
\hline \multirow{4}{*}{50} & Hijau (K1) & 15,33 & 17,83 & 32,33 & 43,00 & $27,12^{\mathrm{a}}$ \\
& Hitam (K2) & 12,50 & 16,83 & 21,83 & 20,50 & $17,91^{\mathrm{a}}$ \\
& Kuning (K3) & 21,67 & 26,33 & 27,17 & 31,83 & $26,75^{\mathrm{a}}$ \\
\cline { 2 - 6 } & Rerata & $16,50^{\mathrm{b}}$ & $20,33^{\text {ab }}$ & $27,11^{\text {ab }}$ & $31,77^{\mathrm{a}}$ & $(-)$
\end{tabular}

Keterangan: Angka yang diikuti superscript pada baris dan kolom yang diikuti dengan huruf yang sama tidak berbeda nyata menurut uji DMRT $\alpha 5 \%$. ( - ): Tidak terjadi interaksi antar faktor

Tabel 13. Berat kering total

\begin{tabular}{|c|c|c|c|c|c|c|}
\hline \multirow{2}{*}{$\begin{array}{c}\text { Waktu } \\
\text { Pengamatan } \\
\text { HST }\end{array}$} & \multirow{2}{*}{$\begin{array}{c}\text { Jenis Kacang } \\
\text { Hijau }\end{array}$} & \multicolumn{4}{|c|}{ Takaran Kompos Biochar (t/ha) } & \multirow[b]{2}{*}{ Rerata } \\
\hline & & $\begin{array}{c}\text { Kontrol } \\
\text { (B0) }\end{array}$ & $10(\mathrm{~B} 1)$ & $15(\mathrm{~B} 2)$ & 20(B3) & \\
\hline \multirow{4}{*}{35} & Hijau (K1) & 0,56 & 0,89 & 1,24 & 0,63 & $0,83^{\mathrm{a}}$ \\
\hline & Hitam (K2) & 0,44 & 1,41 & 1,59 & 0,78 & $1.05^{\mathrm{a}}$ \\
\hline & Kuning (K3) & 1,49 & 1,34 & 1,70 & 1,38 & $1,47^{\mathrm{a}}$ \\
\hline & Rerata & $0,83^{\mathrm{a}}$ & $1,21^{\mathrm{a}}$ & $1,51^{\mathrm{a}}$ & $0,99^{\mathrm{a}}$ & $(-)$ \\
\hline \multirow{4}{*}{50} & Hijau (K1) & 4,04 & 2,57 & 4,33 & 1,74 & $3,17^{\mathrm{a}}$ \\
\hline & Hitam (K2) & 2,49 & 3,68 & 6,75 & 2,42 & $3,84^{\mathrm{a}}$ \\
\hline & Kuning (K3) & 4,16 & 4,86 & 3,65 & 2,59 & $3,82^{\mathrm{a}}$ \\
\hline & Rerata & $3,56 \mathrm{ab}$ & $3,70^{\mathrm{ab}}$ & $4,91^{\text {a }}$ & $2,25^{\mathrm{b}}$ & $(-)$ \\
\hline
\end{tabular}

Keterangan: Angka yang diikuti superscript pada baris dan kolom yang diikuti dengan huruf yang sama tidak berbeda nyata menurut uji DMRT a 5\%.( - ): Tidak terjadi interaksi antar faktor.

\section{Berat Kering Berangkasan}

Hasil sidik ragam (Anova) menunjukkan tidak terjadi interaksi antara perlakuan jenis kacang hijau dan takaran kompos biochar terhadap parameter pengamatan berat kering berangkasan. Aras perlakuan jenis kacang hijau menunjukkan bahwa tidak terjadi beda nyata sedangkan perlakuan takaran kompos biochar menunjukkan adanya beda dengan takaran kompos biochar 15 t/ha lebih berat yang berbeda sangat nyata dengan perlakuan 20 t/ha (Tabel 14) Tingginya berat berangkasan pada takaran kompos biochar $15 \mathrm{t} / \mathrm{ha}$ mungkin disebabkan oleh hara yang terdapat dalam kompos sudah cukup optimum tersedia bagi pertumbuhan dan perkembangan tanaman aras perlakuan lainnya sehingga tajuk tanaman lebih subur.

Tabel 14. Berat kering berangkasan per tanaman $(\mathrm{g})$ saat panen

\begin{tabular}{lccccc}
\hline \multirow{2}{*}{ Jenis Kacang Hijau } & \multicolumn{5}{c}{ Takaran Kompos Biochar (t/ha) } \\
\cline { 2 - 5 } & Kontrol (B0) & $10(\mathrm{~B} 1)$ & $15(\mathrm{~B} 2)$ & $20(\mathrm{~B} 3)$ & \\
\hline Hijau (K1) & 4,94 & 3,72 & 6,21 & 3,66 & $4,63^{\mathrm{a}}$ \\
Hitam (K2) & 3,50 & 4,85 & 8,31 & 3,77 & $5,10^{\mathrm{a}}$ \\
Kuning (K3) & 5,31 & 6,13 & 5,99 & 4,34 & $5,44^{\mathrm{a}}$ \\
\hline \multicolumn{1}{c}{ Rerata } & $4,58^{\mathrm{ab}}$ & $4,90^{\mathrm{ab}}$ & $6,83^{\mathrm{a}}$ & $3,92^{\mathrm{b}}$ & $(-)$ \\
\hline
\end{tabular}

Keterangan: Angka yang diikuti superscript pada baris dan kolom yang diikuti dengan huruf yang sama tidak berbeda nyata menurut uji DMRT $\alpha$ 5\%.( - ): Tidak terjad interaksi antar faktor.

\section{Jumlah Polong Per Tanaman}

Hasil sidik ragam (Anova) menunjukkan terjadi interaksi antara perlakuan jenis kacang hijau dan takaran kompos biochar terhadap parameter pengamatan jumlah polong pertanaman. Kombinasi perlakuan jenis kacang hijau fore belu dengan takaran kompos biochar 20 t/ha menghasilkan Jumlah polong pertanaman paling tinggi yang berbeda sangat nyata dengan kombinasi perlakuan lainnya (Tabel 15). Hal ini disebabkan oleh konversi unsur hara yang terdapat dalam kompos sangat cukup untuk pembentukkan polong, selain itu konversi nitrogen yang disuplai dari bintil akar sangat efektif pada saat pembentukkan polong kacang hijau dibandingkan jenis kacang lainnya.

Tabel 15. Jumlah Polong PerTanaman

\begin{tabular}{lccccc}
\hline \multirow{2}{*}{ Jenis Kacang Hijau } & \multicolumn{5}{c}{ Takaran Kompos Biochar (t/ha) } \\
\cline { 2 - 6 } & Kontrol (B0) & $10(\mathrm{~B} 1)$ & $15(\mathrm{~B} 2)$ & $20(\mathrm{~B} 3)$ & \\
\hline Hijau (K1) & $8,77 \mathrm{~cd}$ & $14,11 \mathrm{bcd}$ & $20,55 \mathrm{~b}$ & $29,55 \mathrm{a}$ & $18,24^{\mathrm{a}}$ \\
Hitam (K2) & $7,33 \mathrm{~cd}$ & $9,22 \mathrm{~cd}$ & $8,90 \mathrm{~cd}$ & $8,11 \mathrm{~cd}$ & $8,38 \mathrm{~b}$ \\
Kuning (K3) & $5,44 \mathrm{c}$ & $7,77 \mathrm{~cd}$ & $10,66 \mathrm{~cd}$ & $15,05 \mathrm{bc}$ & $9,73 \mathrm{~b}$ \\
\hline Rerata & $7,18^{\mathrm{c}}$ & $10,37^{\mathrm{bc}}$ & $13,37^{\mathrm{ab}}$ & $17,57^{\mathrm{a}}$ & $(+)$ \\
\hline
\end{tabular}

Keterangan: Angka yang diikuti super script pada baris dan kolom yang diikuti dengan huruf yang sama tidak berbeda nyata menurut uji DMRT a 5\%.( - ): Tidak terjadi interaksi antar faktor.

\section{Jumlah Biji Per Polong}

Hasil sidik ragam (Anova) menunjukkan tidak terjadi interaksi antara perlakuan jenis kacang hijau dan takaran kompos biochar terhadap parameter pengamatan jumlah polong pertanaman. Aras perlakuan jenis kacang hijau lebih sedikit membentuk polong yang berbeda nyata dengan kacang kuning dan kacang hitam sedangkan aras perlakuan takaran kompos biochar 15 t/ha menghasilkan jumlah biji per polong lebih banyak yang berbeda sangat nyata dengan kontrol (Tabel 16).

Tabel 16. Jumlah Biji/Polong

\begin{tabular}{lccccc}
\hline \multirow{2}{*}{$\begin{array}{c}\text { Jenis Kacang } \\
\text { Hijau }\end{array}$} & \multicolumn{3}{c}{ Takaran Kompos Biochar (t/ha) } & \multirow{2}{*}{ Rerata } \\
\cline { 2 - 5 } & (B0) & $10(\mathrm{~B} 1)$ & $15(\mathrm{~B} 2)$ & $20(\mathrm{~B} 3)$ & \\
\hline Hijau (K1) & 10,40 & 11,63 & 11,50 & 11,26 & $11,20 \mathrm{~b}$ \\
Hitam (K2) & 11,23 & 12,36 & 12,86 & 12,36 & $12,20 \mathrm{a}$ \\
Kuning (K3) & 12,10 & 12,90 & 13,10 & 12,23 & $12,58 \mathrm{a}$ \\
\hline Rerata & $11,24^{\mathrm{b}}$ & $12,30^{\mathrm{a}}$ & $12,48^{\mathrm{a}}$ & $11,55^{\text {ab }}$ & $(-)$ \\
\hline
\end{tabular}

Keterangan: Angka yang diikuti superscript pada baris dan kolom yang diikuti dengan huruf yang sama tidak berbeda nyata menurut uji DMRT a 5\%.( - ): Tidak terjadi interaksi antar faktor.

Kacang hijau kultivar kuning dan hitam cenderung untuk membentuk polong lebih panjang daripada kacang hijau sehingga pembentukkan ruang biji lebih banyak, hal ini sangat dipengaruhi oleh faktor internal atau potensi genetik yang dimiliki sehingga pada saat penambahan takaran kompos biochar kedalam tanah potensi tersebut diakomodir oleh tanam dalam bentuk jumlah biji per plong lebih banyak.

\section{Berat Biji Per Tanaman}

Hasil sidik ragam (Anova) menunjukkan tidak terjadi interaksi antara perlakuan jenis kacang hijau dan takaran kompos biochar terhadap parameter pengamatan berat biji pertanaman. Aras perlakuan jenis kacang hijau menunjukkan beda nyata dengan jenis kacang hijau fore belu menghasilkan berat biji per tanaman paling berat dan berbeda sangat nyata dengan jenis kacang kuning, hal ini menunjukkan bahwa tanaman kacang hijau memiliki potensi berat per tanaman lebih baik karena jumlah polong yang dihasilkan lebih banyak walaupun jumlah biji yang dihasilkan per polongnya lebih sedikit. Aras perlakuan takaran kompos biochar menunjukkan bahwa takaran kompos biochar 20 t/ha menghasilkan berat biji pertanaman lebih berat dan berbeda sangat nyata dengan kontrol (Tabel 17). Hal ini menunjukkan bahwa dengan menambahkan kompos biochar kedalam tanah kacang mampu memberikan potensi terbaiknya sehingga menghasilkan jumlah polong lebih banyak sehingga akumulasi berat biji per tanaman lebih berat.

\section{$\underline{\text { Tabel 17. Berat Biji/Tanaman (g) }}$}

\begin{tabular}{lccccc}
\hline \multirow{2}{*}{$\begin{array}{c}\text { Jenis Kacang } \\
\text { Hijau }\end{array}$} & \multicolumn{4}{c}{ Takaran Kompos Biochar (t/ha) } & \\
\cline { 2 - 5 } & Kontrol & 10 & 15 & $20(\mathrm{~B} 3)$ & \multirow{2}{*}{ Rerata } \\
\hline Hijau (K1) & 3,25 & $(\mathrm{~B} 1)$ & $(\mathrm{B} 2)$ & & \\
Hitam (K2) & 2,32 & 5,97 & 7,92 & 12,28 & $7,35 \mathrm{a}$ \\
Kuning (K3) & 4,00 & 4,89 & 5,62 & 5,46 & $4,69 \mathrm{~b}$ \\
\hline Rerata & $3,19 \mathrm{c}$ & $5,41 \mathrm{bc}$ & $7,02 \mathrm{ab}$ & $9,07 \mathrm{a}$ & $(-)$ \\
\hline
\end{tabular}

Keterangan: Angka yang diikuti superscript pada baris dan kolom yang diikuti dengan huruf yang sama tidak berbeda nyata menurut uji DMRT a 5\%.( - ): Tidak terjadi interaksi antar faktor.

\section{Berat Biji Per Petak}

Hasil sidik ragam (Anova) menunjukkan tidak terjadi interaksi antara perlakuan jenis kacang hijau dan takaran kompos biochar terhadap parameter pengamatan berat biji perpetak. Aras perlakuan jenis kacang menunjukkan tidak berbeda nyata. Aras perlakuan takaran kompos biochar menunjukkan bahwa takaran kompos biochar 15 t/ha menghasilkan berat biji per petak lebih tinggi dan berbeda sangat nyata dengan aras perlakuan lainnya (Tabel 18).

Tabel 18. Berat Biji/Petak (g)

\begin{tabular}{|c|c|c|c|c|c|}
\hline \multirow[b]{2}{*}{$\begin{array}{c}\text { Jenis Kacang } \\
\text { Hijau }\end{array}$} & \multicolumn{4}{|c|}{ Takaran Kompos Biochar (t/ha) } & \multirow[b]{2}{*}{ Rerata } \\
\hline & $\begin{array}{c}\text { Kontrol } \\
\text { (B0) }\end{array}$ & $10(\mathrm{~B} 1)$ & $15(\mathrm{~B} 2)$ & 20 (B3) & \\
\hline$\overline{\text { Hijau (K1) }}$ & 78,62 & 118,35 & 180,97 & 193,53 & $142,87 \mathrm{a}$ \\
\hline Hitam (K2) & 77,40 & 103,04 & 139,19 & 129,63 & $112,31 \mathrm{a}$ \\
\hline Kuning (K3) & 100,01 & 116,50 & 208,84 & 168,53 & $148,56 \mathrm{a}$ \\
\hline
\end{tabular}

Keterangan: Angka yang diikuti superscript pada baris dan kolom yang diikuti dengan huruf yang sama tidak berbeda nyata menurut uji DMRT $\alpha$ 5\%.( - ): Tidak terjadi interaksi antar faktor.

Penambahan kompos biochar kedalam tanah meningkatkan berat biji per petak hal ini sebagai bukti bahwa penambahan bahan organik yang mengandung unsur hara sangat penting untuk pembentukkan dan pengisian biji sehinga biji menjadi lebih bernas.

\section{Berat 100 Biji}

Hasil sidik ragam (Anova) menunjukkan tidak terjadi interaksi antara perlakuan jenis kacang hijau dan takaran kompos biochar terhadap parameter pengamatan berat 100 biji. 
Tabel 19. Berat 100 biji (g)

\begin{tabular}{lccccc}
\hline \multirow{2}{*}{ Jenis Kacang Hijau } & \multicolumn{4}{c}{ Takaran Kompos Biochar (t/ha) } & \multirow{2}{*}{ Rerata } \\
\cline { 2 - 5 } & Kontrol (B0) & $10(\mathrm{~B} 1)$ & $15(\mathrm{~B} 2)$ & $20(\mathrm{~B} 3)$ & \\
\hline Hijau (K1) & 4,94 & 5,29 & 5,93 & 5,09 & $5,31 \mathrm{a}$ \\
Hitam (K2) & 4,96 & 5,49 & 6,14 & 5,96 & $5,64 \mathrm{a}$ \\
Kuning (K3) & 5,08 & 5,70 & 5,56 & 5,71 & $5,51 \mathrm{a}$ \\
\hline Rerata & $4,99 \mathrm{~b}$ & $5,49 \mathrm{a}$ & $5,87 \mathrm{a}$ & $5,59 \mathrm{a}$ & $(-)$ \\
\hline
\end{tabular}

Keterangan: Angka yang diikuti superscript pada baris dan kolom yang diikuti dengan huruf yang sama tidak berbeda nyata menurut uji DMRT a 5\%.( - ): Tidak terjadi interaksi antar faktor.

Aras perlakuan jenis kacang menunjukkan bahwa tidak terjadi beda nyata antar aras jenis kacang hijau. Jenis kacang hitam memiliki berat 100 biji lebih berat yang berarti biji kacang pada jenis kacang hitam memiliki ukuran lebih besar dan juga padat. Perlakuan tanpa kompos biochar menghasilkan berat 100 biji paling rendah yang berbeda sangat nyata dengan penggunaan kompos biochar (Tabel 19). Hal ini menunjukkan bahwa dengan menambahkan kompos biochar kedalam tanah dapat memperbesar ukuran biji kacang hijau.

\section{Berat Biji Per Hektar}

Hasil sidik ragam (Anova) menunjukkan tidak terjadi interaksi antara perlakuan jenis kacang hijau dan takaran kompos biochar terhadap parameter pengamatan berat biji perhektar. Aras perlakuan jenis kacang menunjukkan bahwa tidak terjadi beda nyata antara aras perlakuan. Aras perlakuan takaran kompos biochar menunjukkan bahwa berat biji per hektara paling rendah dihasilkan oleh perlakuan tanpa kompos biochar yang berbeda sangat nyata dengan takaran kompos biochar 15 t/ha (Tabel 20). Tanaman kacang yang diberikan kompos biochar menghasilkan berat biji per hektar lebih tinggi sebagai akibat komponen pendukung hasil tanaman seperti jumlah polong dan jumlah biji per polong lebih banyak menyebabkan berat biji per tanaman, berat biji per petak dan berat 100 biji lebih tinggi yang terakumulasi dalam berat biji perhektarnya lebih tinggi pula.

Tabel 20. Berat Biji/ha (t/ha)

\begin{tabular}{lccccc}
\hline \multirow{2}{*}{ Jenis Kacang Hijau } & \multicolumn{4}{c}{ Takaran Kompos Biochar (t/ha) } & \multirow{2}{*}{ Rerata } \\
\cline { 2 - 5 } & Kontrol (B0) & $10(\mathrm{~B} 1)$ & $15(\mathrm{~B} 2)$ & $20(\mathrm{~B} 3)$ & \\
\hline Hijau (K1) & 0,24 & 0,37 & 0,56 & 0,60 & $0,44 \mathrm{a}$ \\
Hitam (K2) & 0,24 & 0,32 & 0,43 & 0,40 & $0,35 \mathrm{a}$ \\
Kuning (K3) & 0,31 & 0,6 & 0,65 & 0,53 & $0,46 \mathrm{a}$ \\
\hline Rerata & $0,26 \mathrm{c}$ & $0,35 \mathrm{bc}$ & $0,55 \mathrm{a}$ & $0,51 \mathrm{ab}$ & $(-)$ \\
\hline
\end{tabular}

Keterangan: Angka yang diikuti superscript pada baris dan kolom yang diikuti dengan huruf yang sama tidak berbeda nyata menurut uji DMRT a 5\%.( - ): Tidak terjadi interaksi antar faktor.

\section{Indeks Panen}

Hasil sidik ragam (Anova) menunjukkan tidak terjadi interaksi antara perlakuan jenis kacang hijau dan takaran kompos biochar terhadap parameter pengamatan indeks panen. Aras perlakuan jenis kacang menunjukkan bahwa tidak terjadi beda nyata antara aras perlakuan, sedangkan perlakuan takaran kompos biochar menunjukkan bahwa terjadi beda nyata yang mana takaran kompos biochar 20 t/ha menghasilkan indeks panen paling tinggi (Tabel 21). Hal ini berarti bahwa persentase pembentukkan hasil fotosintetis lebih banyak diarahkan untuk pembentukkan biji dibandingkan dengan pembentukkan tajuk tanaman.

\section{Tabel 21. Indeks Panen}

\begin{tabular}{lccccc}
\hline \multirow{2}{*}{ Jenis Kacang Hijau } & \multicolumn{5}{c}{ Takaran Kompos Biochar } \\
\cline { 2 - 6 } & Kontrol (B0) & 10 t/ha (B1) & 15 t/ha (B2) & 20 t/ha (B3) & \\
\hline Hijau (K1) & 40,67 & 62,93 & 55,23 & 77,82 & 59,16 a \\
Hitam (K2) & 47,26 & 51,95 & 42,59 & 55,98 & $49,44 \mathrm{a}$ \\
Kuning (K3) & 44,89 & 44,41 & 54,00 & 66,67 & $52,49 \mathrm{a}$ \\
\hline Rerata & $44,27 \mathrm{~b}$ & $53,09 \mathrm{~b}$ & $50,60 \mathrm{~b}$ & $66,82 \mathrm{a}$ & $(-)$ \\
\hline
\end{tabular}

Keterangan: Angka yang diikuti superscript pada baris dan kolom yang diikuti dengan huruf yang sama tidakberbeda nyata menurut uji DMRT $\alpha$ \%\%.( - ): Tidak terjadi interaksi antar faktor.

\section{Simpulan}

Berdasarkan hasil penelitian dapat disimpulkan bahwa tidak terjadi interaksi antara perlakuan takaran kompos biochar dengan jenis kacang terhadap semua parameter pengamatankecuali pada parameter pengamatan tinggi tanaman 21 hst, panjang akar 35 hst, total bintil akar 50 hst, dan jumlah polong per tanaman. Kompos biochar berpengaruh terhadap suhu tanah, tinggi tanaman 21 dan 28 hst, jumlah daun 42 hst, diameter batang 42 hast, luas daun 35 hst, berat kering daun 35 hst, panjang akar 35 dan 50 hst, berat kering akar 50 hst, total bintil akar 35 dan 50 hst, bintil akar efektif 35 dan 50 hst, berat kering total tanaman 50 hst, berat kering berangkasan saat panen, jumlah polong per tanaman, jumlah biji per polong, berat bijiper tanaman, berat biji per petak, berat 100 biji, berat biji per hektar, dan indeks panen.Jenis kacang berpengaruh terhadap tinggi tanaman 14 hst, jumlah daun 14 dan 21 hst, berat kering akar 35 hst, total bintil akar 35 hst, jumlah polong per tanaman, jumlah biji per polong, dan berat biji per tanaman. Takaran terbaik untuk jenis kacang hijau fore belu adalah 20t/ha, kuning 15 t/ha, hitam 15 t/ha.

\section{Pustaka}

Agegnehu, G., Adrian, M.B., Paul, N.N., \& Michael I.B. 2016 a. Benefits of biochar, compost and biochar-compost for soil quality, maize yield and greenhouse gas emissions in a tropical agricultural soil. Elsevier, Science of The Total Environment. Vol.543, Part (A): 295-306.

Atman.2007.Teknologi Budidaya Kacang Hijau (Vignaradiata L.) di Lahan Sawa. Jurnal Ilmiah Tambua.VI (1):89-95. ISSN 1412-5838.

BPS Nasional. 2016. Statistik Pertanian Tanaman Pangan Nasional. diunduh 26 September 2018. Tersedia pada https://www.bps.go.id.

Berek, A.K., Tabati, P.O., Keraf, U.U., Bere, E., Taekab, R. \& Wora, A. 2017. Perbaikan Pertumbuhan dan Hasil Kacang Tanah di Tanah Entisol Semi arid melalui Aplikasi Biochar.Savana Cendana, 2(03): 5658.

Borchard N., K. Prost., T. Kautz., A. Moeller., \& J. Siemens. 2012. Sorption of copper (II) and sulphate to different biochars before and after composting with farmyard manure. European Journal of soil science. Vol.63 (3): 399-409.

Dias, B.O., C.A. Silva., F.S. Higashikawa., A. Roig \& M. A. SánchezMonedero. 2010. Use of biochar as bulking agent for the composting of poultry manure: Effect on organic matter degradation and humification. Elsevier-Bioresource Technology. Volume 101 (4): 1239-1246.

Ekebafe, M.O., L.O. Ekebafe \& S.O. Ugbesia. 2015. Biochar composts and composites. Science Progress. Vol 98 (2): 169-176.

Gomez, K.A. dan Gomez,A.A. 2010. Prosedur Statistik Untuk Penelitian Pertanian. Edisi ke-2. UI Pres : Jakarta

Kamlasi, M., S. Ceunfin 2018. Pengaruh Jenis Teh Kompos dan Mulsa Organik terhadap Pertumbuhan dan Hasil Tanaman Kacang Mungo (Vigna mungo (L.) Hepper) Var. Lokal Timor.Savana Cendana Vol 3(2):29-32.

Kolo, 2018. Pengaruh Jenis Kompos Biochar Terhadap Pertumbuhan dan Hasil Dua Kultivar Kacang Hijau (Vigna radiate L.) [Skripsi] Fakultas Pertanian Universitas Timor.

Nur, M. S. M.; Islami, T.; Handayanto, E.; Nugroho, W. H.; Utomo, W. H., 2014. The use of biochar fortified compost on calcareous soil of East Nusa Tenggara, Indonesia: 2. Effect on the yield of maize (Zea mays L) and phosphate absorption. American-Eurasian Journal of Sustainable Agriculture. Vol 8 (5): 105-111.

Neonbeni, E., \& Seran, A. (2017). Pengaruh Takaran Guano dan kosentrasi The Kompos terhadap pertumbuhan dan Hasil Kacang Hijau (Vigna radiata L.) Savana Cendana, 2(03), 42-45.

Qayyum, M. F., Fatima L., Rabia A. R., Mehreen G., Muhammad Z. H., Muhammad R. \& Muhammad Z. R. 2017. Effects of co-composting of farm manure and biochar on plant growth and carbon mineralization in an alkaline soil. Environmental Science and Pollution Research. Vol 24 933): 26060-26068.

Schulz, H., Gerald D. \& Bruno G. 2013. Positive effects of composted biochar on plant growth and soil fertility. Agronomy for Sustainable Development. Vol. 33 (4): 817-827.

Sitompul S.M dan Guritno Bambang. 1995. Pertumbuhan Tanaman., Gadjah Mada University Press, Yogyakarta.

Soediarto. A., Koesoemaningrat. T., Natasaputra. M., Akmal Hilda 1992.Anatomi Tumbuhan., Gadjah Mada University Press. Yogyakarta. 